\title{
Renata Jasnos, Deuteronomium jako „księga” w kontekście kultury piśmienniczej starożytnego Bliskiego Wschodu, Akademia Ignatianum, Wydawnictwo WAM, Kraków 2011, 485 pp. (Humanitas. Studia Kulturoznawcze. Badania)
}

The work presented in this review shows the creation of the Book of Deuteronomy in the broad context of writing and culture in the ancient Near East.

The paper consists of three parts. The first one is devoted to the selected aspects of the writing culture in the ancient Near East, with particular focus on Israel and Judea. The introduction shows the beginnings and the development of writing and writing culture (p. 27-36), the second chapter discusses the beginnings and the development of the scribal culture in Israel and Judea: the history of writing in the researched area - from the Cuneiform script in Canaan through the attempts leading to the creation of the alphabet, to Hebrew writing; the level of literacy in the areas of biblical Israel and Judea in $12^{\text {th }}-9^{\text {th }}$ and $8^{\text {th }}-6^{\text {th }}$ centuries; the conditionings of the development of writing in Israel and Judea: cultural, economically - administrative, social and political; the historical aspect of literacy in biblical accounts; the linguistic situation and literacy in the Persian period and the scribal culture of Israel and Judea: text storing places - archives, people creating and copying the texts - writers (archaeological and biblical data, titles and names of biblical writers, writing functions, writing skills, level of education, pre-exile families of 
writers, the connections of courtly writers with the temple, the question of writers' education (p. 37-91). The third chapter of the first part discusses selected aspects of the cultural context of the writings in the Near East: text functions, ancient perception of writing and text recording (the belief in the incredible power of writing, mythical association of writing with gods and magic in Egypt and Mesopotamia), written record of extraordinary content - secret knowledge and letters of gods, the concept of authorship and the authority of the text, the tension between invention and duplicating the content (p.93-134). The fourth chapter concerns the question of intercultural interactions: the evaluation of the cultural influences phenomenon, the significance of Ugarit as a mediator and witness of cultural influences caused by historical phenomena, the interruption, continuation and adaptation of the influences. It finishes with a question concerning research taking into account parallels in the cultural environments which shaped biblical authors, and the originality of the Bible in comparison with the prevailing cultural influences (p. 135-145).

Part two is entitled: "Deuteronomy as sêfer" and also consists of four chapters. The first one discusses the terminology connected with writing: sêfer as a piece of writing, letter, written documents; the verb kätab, which means 'to write'; other terms associated with writing meaning 'writer' and at the same time 'superior' or ' a divorce letter'; less commonly used terms connected with writing as well as ambiguous terms referring to a word in general and to its different forms and the word törāh meaning science - law (p. 149-170). The second chapter presents selected aspects of the scribal culture in Deuteronomy: the material aspect - writing tools and materials; the personal aspect - who the writer is, types and functions of writing; Deuteronomy as a written work - what it includes as a book of law, the covenant and the meaning of "words", the relation between the Book of Deuteronomy and the "Book" of Torah, aims and functions of the "Book" of Torah in Deuteronomy, the relation between the "Book" of Torah and the stone tablets in Deuteronomy and the Book of Exodus (p. 171-218). The third chapter talks about the "Book" of Torah in other traditions of the Hebrew Bible: the Book of Joshua, the Books of Kings, the Books of Chronicles, the Book of Ezra, the Book of Nehemiah and the prophetic books of the Old Testament (p. 219-238). 
In the fourth chapter, the structure of the Book of Deuteronomy in the process of forming the text is presented, with special emphasis on the context, form, its complex structure and the terminology analysis with reference to its structure (p. 239-254).

Part three, which consists of five chapters, is devoted to Deuteronomy as the element of culture. The first chapter is entitled: "Oral and written tradition in Deuteronomy". The author discusses the relation between the rhetoric of a literary text and the primary oral form. She presents the characteristic features of the oral message in literature: repetitions, formative style, performance (instructions presented in a nice and dynamic form, meant to be remembered), oral forms of law presentation. She tries to assess the oral dimension of Deuteronomy and show the oral and written dynamism of this book. In the last part of the chapter the author discusses the changes that took place in the oral record under the influence of writing (p. 257-280). The second chapter analyses the revealed wisdom and knowledge in Deuteronomy: Revelation and record as the work of God and Moses, the comparison between the secret knowledge of neighbouring peoples and the biblical wisdom as a domain and gift of God and Moses and the mythical wise man apkallü (p. 281-297). The third chapter shows the written law, its aims and functions, with particular emphasis on the divine right of kings and its reference to the revealed law in the context of Near-Eastern concept of power; laws and other legal writings; two stone tablets and the Ten Words of Jhwh and the function of the chest (the Ark of the Covenant) with reference to mythological records, inscriptions of treatises and the country law - the fact that the Law of God was announced in the Promised Land was a proof that the land itself was bestowed on the people of Israel by God (p. 299-336). Chapter four is the analysis of the process of shaping Deuteronomy as a piece of writing, which results in a new method of research on the composition of old texts: Kompositionsgeschichte - the history of composition, which, unlike the editorial history, emphasises the gradual introduction of changes in the message which is not treated as a piece of writing of a particular author, but as the image of tradition enriched throughout the centuries depending on the needs and prevailing conditions. The author points out the relation between the elements of the literary workshop and the 
process of text composition. She uses 'the model of Gilgamesh' as a point of reference for the identification of particular stages of the book development, introduces it to the new research method of Kompositionsgeschichte and makes attempts to confront it with selected theories. She draws the readers' attention to the complexity of the message, gives examples of the negative hypothesis verification: the image of the king in Deuteronomy as opposed to the Books of Kings, discusses the 'editions' of the Book of Deuteronomy in accordance with the most recent material available on the subject (p. 337-376). The last chapter presents the synthesis of the Scripture theology and writing in Deuteronomy through the analysis of the oral and written record, characteristics of God as a writer, the mediators of the revelation in the tradition of Deuteronomy, the authority of the text and its significance deriving from the authority of its writer and his words, as well as the importace of writing on the basis of the covenant document, written laws and knowledge (p. 377-398).

The conclusion sums up the research presented in the dissertation.

The English summary makes the basic concepts of the work available to foreign readers. The list of Tables gives quick access to data presented in the book.

The vast Bibliography includes many interesting texts, mostly in English, but also in Polish and four other languages, divided into four sections:

1. The Ancient Near-East and the Writing Culture (p. 428-441);

2. The Writing Culture in the Bible (p. 441-450);

3. The Book of Deuteronomy (p. 450-456);

4. Others (including introductions and commentaries on other biblical books; p. 457-462).

The book includes various Indices, e.g. Subject Index, Biblical Reference Index, and others.

The text is written in a clear, comprehensive style. Detailed introductions and summaries at the beginning and end of each part of all chapters show and help follow the correlation of particular research elements and the course of research itself.

The dissertation is an example of an extraordinary academic achievement, valuable not only for biblical scholars and theologians, but also for other representatives of contemporary Humanistic Studies. It shows the 
author's great skill, seen especially clearly in her conscious analysis of the problematic issue of cultural influences, attention to similarities, the use of common motifs, perception of differences and their use to express different content (from p. 135) as well as the method of Kompositionsgeschichte, which shows the gradual development of conveying the message of God's Revelation by the chosen ones - prophets - and then recorded and further interpreted by writers - the wise men. Observing the process of the formation of biblical texts we must free ourselves from contemporary intellectual patterns, as well as from Greek and Latin literary concepts, try to understand the intellectual elites of the analysed period and their ways of work and thinking.

The dissertation presented in this review is a perfect example of the appropriate scholarly approach. It enriches Polish biblical literature, sheds new light on the creation and development of the Deuteronomic tradition and serves as great help for everyone interested in biblical issues, as well as the development of writing and culture. 
